\title{
Dancing and Calculating: Culturally sustainable development and globalization in light of two paradigms of socio-cultural evolution
}

\author{
Vjeran Katunarić
}

\section{Abstract}

Globalization challenges the usefulness of different paradigms of socio-cultural evolution and opens the possibility for their hybridization. In this paper, two paradigms of evolution, the transformational (Spencerian) and the variational / selectionist (Darwinian), as discerned by Fracchia and Lewontin (1999), are examined along with their social theoretical counterparts. Most social theories of development are connected to different evolutionary paradigms in different historical contexts. The transformational paradigm prevailed until the end of the Cold War (e.g. theories of modernization), and the selectionist paradigm, in various theoretical forms, thereafter (e.g. Huntington, Eisenstadt). Most developmental policies today prefer the selectionist paradigm in terms of the neoliberal free market. The transformational paradigm in development policies was predominant in the era of the welfare state in the West, and its counterpart in the era of the statism of the East. Sustainable development in a socio-cultural sense is the youngest and the least consistent policy concept, and it is not founded on the evolution paradigms. The concept was launched by the UN as an attempt at mediating, mostly on the grounds of ecological alarms, between the free-market and statist policies. The author considers the hybridization of these two paradigms to be a proper conceptual foundation of sustainable development. On this premise, he expounds the concept of a culturally oriented sustainable development, arguing that hybrids of developmental policies are more suitable for a decent survival of most countries.

\section{KEY WORDS:}

evolution, selection, variation, globalization, culturally sustainable development, developmental hybrids 
"A businessman is a hybrid of a dancer and a calculator" (Paul Valéry).

Valery's aphorism on businessmen was published in 1927 (Valéry 1934), when business-making was still an activity that was aware of its impact on society. In subsequent years, instead of opening the door for a market economy recovery, the Great Depression in Europe facilitated the rise of Fascism. At any rate, a businessman was situated less comfortably in his corporation than he is today, when corporations, mostly banks and financial agencies, operate with no regard to the consequences of their actions for the broader society (cf. Castells 1998). Traditionally, the economy was based on agriculture, as the backbone of the Gemeinschaft, a society composed mostly of peasants and artisans. Moreover, as Karl Polanyi put it, during most of human history the economy was embedded into the social tissue and "the idea of a self-adjusting market implied a stark Utopia. Such an institution could not exist for any length of time without annihilating the human and natural substance of society; it would have physically destroyed man and transformed his surroundings into a wilderness" (Polanyi 2001: 2).

Valery's metaphor of a dancer and a calculator may also be taken to illustrate two different meanings of the evolutionary process of society, which will be discussed as follows. As well as an art form, "dancing" may also be taken as a random, free and basically unpredictable movement similar to the Darwinian paradigm of the evolutionary process. "Calculator", on the other hand, may be taken to illustrate a programmed movement with a fixed purpose - like Spencer's and other teleological schemes of evolution. However, neither is sufficient to explain the contemporary perplexities of globalization. In this paper, the idea of sustainable development as a "hybrid" of these two paradigms of evolution will be taken as a more appropriate form of adaptation and survival for most societies. 


\section{The concepts related to development}

Prior to discerning the specific advantages of the idea of a culturally oriented sustainable development, I will clarify the key terms of relevance along with their different contexts. Firstly, evolution and development, although they literally mean the same, have different historical trajectories (cf. Wuketits and Antweiler 2004). Development originates from the Western Enlightenment era and is close to the teleological idea of "progress". "Progressist" evolutionists are, for example, Herbert Spencer and Karl Marx, regardless of their substantial differences in other theoretical aspects.

Today, development is mainly a policy concept with a penchant for the free-market agenda. It was born in the aftermath of World War II, when the American government launched a project of international economic assistance to underdeveloped countries. Meanwhile, the project, along with a parallel Soviet project of economic assistance to underdeveloped countries in its own geopolitical sphere, was grounded due to an obviously permanent gap between the developed and the underdeveloped (cf. Human Development Report 2013). In such a predicament, development became a catchphrase for business elites in developed countries and their allied elites in underdeveloped countries (cf. Fine 2002).

In the most accepted version of science, evolution is a synonym for the work of Charles Darwin. Unlike Spencer and Marx, he rejected the idea of progress and applied his naturalistic concept to humans as well.' Darwin's central argument about the survival of the fittest through selection constitutes the (neo)evolutionary social theory (Runciman 1989; 2006), although not mainstream sociology (cf. Runciman 2005).

Furthermore, from the 1980s onward, globalization primarily designates the worldwide expansion of economic markets, as well as large-scale operations of corporations worldwide. This expansion entails some new political, military, demographic (e.g. migrations) and cultural processes

\footnotetext{
"For my own part I would as soon be descended from that heroic little monkey, who braved his dreaded enemy in order to save the life of his keeper, or from that old baboon, who descending from the mountains, carried away in triumph his young comrade from a crowd of astonished dogs - as from a savage who delights to torture his enemies, offers up bloody sacrifices, practices infanticide without remorse, treats his wives like slaves, knows no decency, and is haunted by grossest superstitions" (Darwin /1882/ 2002: 619).
} 
(e.g. the growth of cultural industries) (cf. Held and McGrew 2007). These processes challenge the explanatory potential of both paradigms of evolution.

Finally, sustainable development, and culturally sustainable development in particular, are the most recent and least consistent policy concepts, launched by the UN/UNESCO (cf. http://www.uncsd2012.org/history. $\underline{\mathrm{html}}$ ). The adoption of principles of sustainable development corresponds to a variety of economic interests and cultural traditions of the member states (Duxbury and Gillette 2007). This simultaneously represents both the strength and the weakness of the concept. The weakness lies in the fact that the concept is too abstract to be implemented in individual countries. Its strength, on the other hand, is that it opens up the possibility of combining different paradigms of evolution/development, while undercutting their extreme versions, i.e. the free market struggle for survival and the total transformation of society without retention of anything from the past.

\section{Failures of global development without global mechanisms of coordination}

Third world countries have been entitled to American assistance in order to move away from their backwardness (Omar 2012). Meanwhile, the whole enterprise is compromised due to the increasing poverty, deterioration of health conditions and poor educational opportunities in most countries (cf. UN Global Poverty Statistics 2006). Very often, however, this grim picture is concealed behind a standard presentation of data in terms of methodological nationalism. For instance, developmental gaps within the USA or within Burkina Faso are not as big as the gaps between the two countries (see Human Development Report 2013). Nevertheless, developmental problems can be solved on the nation-state level to a progressively decreasing degree. On the other hand, there is no global government or equivalent world organization whose policies would be aimed at closing the global gaps. Meanwhile, policy-makers in most underdeveloped countries 
frame their policies by the "shock therapy" doctrine that imposes freemarket policies, alleged to be the only cure for economies exhausted by those same free-market policies (cf. Klein 2007). As a substitute for lacking mechanisms on the global level, the contemporary global marketplace is ultimately protected by Western and allied military forces.

These global malfunctions fit Darwin's selectionist paradigm. The outcomes of development may be explained as a product of merciless selection in the incessant struggle for survival and hegemony. At the same time, neoclassical social science, and economics in particular, does not provide plausible recommendations for market failures. Instead, market failures are treated as inevitable and as equivalents to natural disasters.

Such a formation of developmental thought is particularly inadequate for peripheries. Both functionalist authors, such as Shils (1975), and Marxist authors, such as Amin (1990), see the periphery as a negative of the centre. The periphery lacks any major resource of power, from private consuming wealth ${ }^{2}$ to know-how. The same gap is replicated in natural sciences and high-tech production (cf. Bürkner and Matthiesen 2007) and in social sciences (Hicks 2013; Katunarić 2011).

Another result of such development is that all sectors become increasingly elitist, including parliament, allegedly the "last bastion" of (representative) democracy, which in fact functions as a lever of small, yet most powerful, groups. At the same time, large corporations in the West collaborate with non-democratic regimes, such as in Saudi Arabia or China. Nevertheless, both democratic and non-democratic regimes advocate the enrichment of the rich and the deepening of socio-economic inequalities, ostensibly as the motor of development. In peripheral countries, in particular, the new elites discard state intervention in economic affairs, unless such interventions are already agreed upon as part of the corruptive chain. Also, there is a growing tendency to replace civil administration with a network of militarypolice outposts, controlled by big corporations. The latter, thus,

2 Amin sees an alternative to capitalism in the periphery in autocentric development, which produces "means of production" and "mass consumer goods", and refrains from luxury goods and exports (Amin 1990: 193). 
behave like feudal lords in the pre-absolutist era in Europe, when the power of the kings, as forerunners of the modern state, was weak.

Generally, unlike modern nation-states in the West, which succeeded in establishing some democratic political standards, the global mutant is not created by (pro)democratic movements, but by contingencies of freemarket globalization, without accompanying regulative mechanisms that operated in nation-states. Is this an inevitable evolutionary outcome?

\section{The two paradigms of socio-cultural evolution}

An idea of socio-cultural evolution emerged decades before Danwin's The Origin of Species in Adam Smith's laudations to the market economy as the playground for the selection of the best qualities of products (cf. Hayek 1979). Another idea of evolution appeared, a few years before Darwin's, in Spencer's work. He argued that everything in the living world evolves and that the process unfolds from simple to complex entities. Concurrently, each individual passes through a process of transformation: from its origin to its end, from birth to death (cf. Fracchia and Lewontin 1999). This tenet fits Spencer's assumption of the linear process of social evolution, in which the military society, as a less complex and basically despotic society, turns into a peaceful and liberal industrial society. Thus, a new society replaces an old society completely.

Darwin, on the other hand, introduced the variational paradigm of evolution. Here, individuals have different properties, and the population bearing these properties in uneven proportions does not depend on individual change. As Fracchia and Lewontin put it, for Darwin developmental changes in the individual organism, with all its variations, including birth, maturing and death, are not mirrored in the ensemble: " $/ / \mathrm{t}$ is that the forces of change internal to [an] organism, leading to production of variant individuals, are causally random with respect to the external forces that influence the maintenance and spread of those variants in the population. Many are 
Marx's theory, for instance, is closer to Spencer's than Darwin's paradigm of evolution. ${ }^{4}$ Marx takes it that capitalism replaces feudalism completely, which reminds of Weber's ideal types. By analogy, socialism, for Marx, should replace all elements of capitalism (with the exception of progress in science and technology). Figuratively, socialism is to capitalism, or capitalism is to feudalism, what airplane is to car and bicycle, respectively. This basically agrees with Spencer's terms of transformation.

Nevertheless, Spencer's theory is not a trademark of social theory today. Rather, social theory is becoming more pluralistic, with a tendency towards combining the selectionist with the progressist agenda. Before discussing the idea of sustainable development as a major alternative of the policy agenda, let us recall a few remarkable works which brought social theory closer to the Darwinian paradigm. One is the work of anthropologist Marshal Sahlins, who rejects the idea of transformational evolution. Rather, he sees the diversity in the evolution of life, from protozoa to mammals, also as being fundamental in the evolution of culture and society. As much as he recognizes the developmental differences between traditional and modern societies, he warns against the modernistic bias. Sahlins argues that the failure of a culture is most probably the result of its success! Well adapted culture is one-sided, its design is specific and its environment narrowly specialized: the "more adapted a culture is, [the] less capable of change it is" (cited in: Kaplan and Manners 1972: 51). Sahlins also remarks that developed societies consume a lion's part of the total energy. ${ }^{5}$

3 Unlike Fracchia's and Lewontin's approach, which is focused on the relevance of Darwinism in cultural anthropology, this paper is focused on the sociological relevance of Darwinism and Spencerianism as regards post-World-WarII developments in the West and the East, that are characterized by divergence and, subsequently, convergence between capitalism and socialism by virtue of building a welfare state which would, ideally speaking, balance between private needs and public goods. Theoretically, the idea of the welfare state may be taken as a forerunner of the idea of sustainable development, since the latter also calls for a compromise between apparently irreconcilable interests.

4 There is an anecdote about the failed communication between Karl Marx and Charles Darwin. Marx sent his Capital (the 1st volume) to Darwin, but never received a response from him. Although Marx appreciated Darwin's work, his regard of Darwin was ambiguous. On the one hand, he admired Darwin's scientific rigor, on the other, he expressed his reservation, stating that Darwin applied the rule of the stock-exchange to the world of nature (cf. Varoufakis 2008).

5 This has to do with the bias of "higher cultures": "No one culture has a monopoly on or even necessarily more kinds of adaptive improvements, and what is selectively advantageous for one may be simply ruinous for another. Nor are those cultures that we might consider in general evolutionary standing necessarily more perfectly adapted to their environments than lower. Many great civilizations have fallen in the last 2,000 years, even in the midst of material plenty, while the Eskimos tenaciously maintained themselves in an incomparably more difficult habitat" (Sahlins 1970: 26-27). 
Consequently, the most developed are least capable of change. So, Sahlin's work represents a rare case of a "humanistic" socio-cultural Darwinism.

A remarkable work in the historical sociology of evolution, based on Darwinian selectionism, is the work of Walter G. Runciman (second volume of his A Treatise on Social Theory, published in 1989). ${ }^{6}$ He defines social evolution in terms of Darwin's paradigm, i.e. non-teleologically, as a moving away and not toward. Hence, history as evolution consists of a neverending set of different processes - stagnations, revolutions, rebellions, turning-points, catastrophes, dead-ends, etc. - with no meaningful direction. Accordingly, "evolution is an incessant competition... (often very violent) ... between rival armies, classes and beliefs". This concurs with Darwin's account: "/F/rom the war of nature, from famine and death, the most exalted objects which we are capable of conceiving, namely the production of higher animals, directly follows." (both quotations are taken from Runciman 1989: 449).

Runciman's approach corresponds to liberal policies of development, for they leave no possibility - for example through planning - to redirect development. This implication also follows the selectionist paradigm, for there is nothing in nature that resembles governance. ${ }^{7}$

Another remarkable theoretical work in accordance with the Darwinian paradigm is Eisenstadt's seminal essay Multiple Modernities (Eisenstadt 2002). He puts forward an idea of a plural modernism, which means that Western, Chinese, Indian, Muslim, Japanese and other national or regional developments, including Islamic fundamentalism, follow different paths. This corresponds with Darwin's "variations" within a general type of development, which in this case is modernity. Yet, Eisenstadt denies that his concept of "multiple modernities" is akin to Huntington's "clash of civilizations", for different paths of development do not necessarily lead to collisions. On the other hand, Eisenstadt's meaning of modernity

6 In 2006 Runciman published a book entitled The Theory of Cultural and Social Selection (Runciman 2006), in which he presented his approach explicitly as selectionist.

7 Note that advocates of the theory and politics of post-development (e.g. Douglas Lummis, Gilbert Rist, Deepak Lal) also oppose the social engineering and managerialism of the welfare-state. As Nederveen Pieterse points out, "there is an elective affinity between neo-liberalism and development agnosticism of post-development" (Nederveen Pieterse 2010: 120). 
is as much relativistic as Huntington's. This is especially important to note where human rights are concerned. Eisenstadt interprets human rights as a cultural, rather than trans-cultural phenomenon and sees modern development basically as a multi-linear process. Yet, how can human rights be understood as a "multi-linear" process? Would different understandings and practices in this regard meet somewhere in the future? Eisenstadt allows that any path of modern development is capable of selfcorrection (Eisenstadt 2002: 24). Yet, he does not explain exactly what this means. It seems that in the case of human rights, the Darwinian approach faces ethical, rather than analytical controversies. It is clear that human rights are violated almost everywhere, but in some regions of the world the human rights rhetoric and legislation are even discarded as a Western imperialistic invention, which is taken as a pretext for oppression against people with different beliefs. If there are no universalistic norms of behaviour in the non-human natural world, this does not mean that they are not worth being established in the human world, in the name of protecting human life and its habitats. As much as the selectionist assumption applied to religious fundamentalism, to racism or to sexism produces major exclusions in society, the selectionist assumption applied to market fundamentalism also leads to a massive exclusion of unemployed persons, whose opportunities for finding new jobs are increasingly diminished. Obviously, the selectionist paradigm needs to be complemented with the transformational paradigm and some universalistic ethos, in order to serve as an important dimension of modern development, and ensure the creation of a sustainable world society.

\section{Contemporary development in light of the two evolutionary paradigms}

In the aftermath of World War II, up until the beginnings of the 1980s, welfarism and mass industrial production were trademarks in the West (Fordism) and the East (statism). Both regimes demonstrated varieties of transformational evolution. At the same time, they represented themselves as the end(s) of history. A further implication of this political eschatology is that it makes any new epoch impossible. Instead, the real, existing regimes can be recycled or expanded infinitely. 
In the 1980s, with the end of the Cold War ideologies, such a prophesized era followed, based on neo-liberalism, i.e. the recycling of classical economic liberalism. Neo-liberalism is much closer to Darwin's selectionism and multi-linear development than it is to Spencer's transformationalism, based on the harmonization of individual competition and cooperation, as well as the unilinear development toward a fairer and post-industrial society. Similarly to early capitalism, neo-liberal capitalism coexists with a variety of regimes, such as crony capitalism, patrimonialism, mono-party dictatorship and monarchism, and tolerates the increasing economic gap, the incurable occurrences of poverty and unemployment and the hyper-production of commodities well (cf. Ziegler 2005). It is also no coincidence that contemporary mass culture imageries increasingly celebrate heroes and narratives based on medieval traditions. ${ }^{8}$

When taking into account the ongoing processes of development, Darwin, Runciman, and even Weber and the positivists might say that the state of the art of today's development reflects the evolutionary course in terms of selectionism. Accordingly, among different populations only a few are successful. On the other hand, for non-Darwinists in social theory the present condition of development is an intended consequence of selectionist-oriented scientists and policy-makers. For the former, who are closer to transformationalism, the modernistic project, which culminates with the welfare state, aspires to certainty and security and thus approaches a solution of the problem of development on the global level. In contrast, neoliberalism embraces uncertainty and risk as a "creative opportunity" (Sörensen and Söderbaum 2012: 13 et passim.). Thus, the policy of material safety and protection has been replaced by politics focused on resilience. Resilience represents a euphemism in relation to continuous global disaster management in which (military) interventions become normal practice. Even ideas and policies of sustainable development are pressured by the imperative of resilience. "/B/uilding resilient subjects presupposes... a world of constant exposure to... catastrophe" (Sörensen and Söderbaum 2012: 14). The bottom line of this criticism focuses on the growing economic instability in the world and the proliferation of wars - for example in Bosnia and Herzegovina, Kosovo, Iraq, Afghanistan, the Ukraine, etc. - as interdependent phenomena.

8 A good part of popular fiction is impregnated with non- or anti-egalitarian subjects - from varieties of the masters of the universe in science fiction to (pseudo)/historical figures of emperors, kings and nobles in popular fiction (ct. Suvin 2010). 
Perhaps, such admonitions of a global catastrophe, still based on a few instances of war, are exaggerated. One may hope so, but the broader picture is disturbing, as it indicates an ongoing paradigm-shift in the Western core countries - primarily in the United States - from state-building societies toward risk-societies, in which corporations in cooperation with traditional or re-traditionalized communities (Castells /1998/ would say: local mafias) break the backbone of Western democracy, based on a more intimate relationship between the state and civil society, where the state served as a protective shield for the citizens and not as a service for big business. The current change brings to mind what medievalist Marc Bloch described as an era predating the establishment of the feudal orders and kingdoms. The era was full of struggles for survival, in which anonymous persons were frequently attacked by bands of robbers, out of which the feudal nobility evolved in the High Middle Ages (Bloch 1989).

Still, the current developmental standoff, though discrediting capitalism, cannot be used for demonizing it. Both capitalism and (former) socialism have significant shortcomings. A minus of capitalism is that it promotes the freedom of entrepreneurs, as a natural selection process", at the expense of socio-economic security and prospects of equality. A minus of (former) socialism is that it promotes social security under authoritarian rule at the expense of freedom (and democracy). By analogy, a minus of the transformational paradigm of evolution is that, actually, no society undergoes a complete transformation, and a minus of the selectionist paradigm is that no society is inclined to endless variation. The best theoretical solution should probably reflect real, rather than stylized, outcomes, mixtures rather than pure types.

Whether and how liberal and socialist policies of development can obtain each other's virtues, and as such be implemented in international politics, is a question that exceeds the scope of this paper. The main tenet of this paper is that the state must be a coordinator of developmental policies, both on the national and on the global level. Today's international scene is a product of the interaction of nearly two hundred states whose relations are contingent upon cycles of globally circulating capitall ${ }^{10}$, rather than

9 As Joseph Stiglitz emphasizes, "/n/atural selection doesn't work well, especially when capital markets are imperfect - which they always are" (Stiglitz 2010: 164, footnote 59).

10 Global capital represents, as Jacques Bidet put it, "a form of state centrality" (Bidet 1999). 
bi- or multilateral agreements, whether in economic or cultural exchange. In such a configuration, a number of nation-states are subservient to big corporations, which act as the new lords who would eventually eliminate or subjugate the modern princes, i.e. nation-states as tax-imposing instances. ${ }^{11}$

In contrast, a responsible world government and democratic parliament would be more appropriate to keep a balance between the corporate interests and the general social interests in development. Such a world-state would have control over financial institutions, such as major banks, which alone, in their capacity of carrying out independent financial policies, have become detrimental to most countries in the world. A financial power, which would be consolidated as a central world bank in the remit of a responsible world government, may significantly contribute to solving the key problem in the human sequence of evolution, namely the survival of the fittest or inclusive fitness. In evolutionary biology these terms signify the number of offspring an organism produces or supports. Inclusive fitness, when translated into Darwinian social theory, means better opportunities for the survival of family circles surrounding the wealthiest or otherwise most successful individuals in a society. The survivalist "We" is, of course, a tiny group. Actually, mankind has never consisted of a single group or community, nor was it ever a cosmopolitan multitude. Although modern societies have significantly extended We-feelings in some parts of their populations, beyond their ethnic or religious boundaries, the magnitudes of a modern We, such as EU citizenship, are suspected to retreat to old boundaries and borders whenever economic crisis hits society (cf. Wallerstein 1990). On the other hand, for a government responsible to the whole world, Africa, or any major underdeveloped area, could no longer be an extraneous, i.e. some other peoples', problem. In a cosmopolitan state, all important developmental issues are common and part of the government's internal affairs.

Last, but not least, a new public sector may be created in place of the old one, which was a residual place in the (Hegelian) triangle between Family, Market and State (Hegel 1979). In place of the "tunnel", through which working people pass on the way between their home and their

11 Consequently, capital evades higher taxes and prefers corporate tax havens such as the Maldives, Kuwait, Ireland, Qatar, Saudi Arabia, Hong Kong - China, Singapore, the U.A.E., etc. 
workplace, the new public sector may diverge the route and become an area of regular meetings between different people. Likewise, instead of the rise of new poverty, of the "bottom billion" up to the "bottom two billion", so to speak, new policies would knit a global safety-net for (temporary) losers in competitive games, in order to make them capable of competing again, of course, if they wanted to.

\section{A project of a culturally oriented sustainable development}

Trends in development theories today - from neoclassical to postmodern, and, among the latter, primarily alternative and sustainable development theories - are impregnated with melancholy and double bind, particularly among radical critics of capitalism. These critics acknowledge that they do not have a vision of a society that could outdo capitalism. Instead, the alternative imagery recurs to worlds of local communities, preoccupied with environmental issues and post-social interests (Knorr-Cetina 1997). In general, it seems that communal movements, both communist and communitarian, exhibit illusory aspirations vis-à-vis the colossal capitalistic Network (Castells 1998). ${ }^{12}$ At the same time, radical visions - created by Amin, Therborn, Habermas, Wallerstein, Touraine, Žižek, and other anticapitalist critics - are inadequate as far as the developmental problems of (semi)peripheral countries are concerned. What these countries can do, that would, at the same time, be acceptable to the core countries, is not clear. Instead, the periphery always fails at what the core succeeds at, be it in terms of economic efficiency or political democracy. Also, owing to its poor skills, with no impact on its developmental outlooks, especially in research and development, the periphery looks like a headless body. ${ }^{13}$

12 Castells' communal haven is a metaphor that designates the lack of power of virtually all anti-capitalist movements. At the same time, he himself acknowledges that he has "exhausted his energy" of imagining a better future. Moreover, he maintains that humankind is "socially underdeveloped", unlike informational technology which, for him, is overdeveloped (Castells 1998: 359).

13 This reminds me of some local museums (which I had the opportunity to visit), in which traditional costumes of nobility and the middle class were presented on wooden mannequins with heads and faces, whereas mannequins displaying the costumes of people from rural areas most often were either head-or face-less. 
Perhaps, the first step in removing the barriers for peripheral development is to revise the concept of periphery in order to make it more vibrant and susceptible to developmental alternatives. For example, the semiperiphery, as conceived by Wallerstein (1992), is the analytical concept that describes it as a zone which, indeed, is more developed than the periphery but, like the periphery itself, is not capable of creating an alternative route of development vis-à-vis the core capitalism. In a more optimistic sense, a semi-periphery might be a zone of the world that combines different types of development policies more easily than policies in the core and the periphery, respectively. Likewise, instead of its ordinary role, according to Wallerstein's model, of control over peripheries - i.e. servicing the core in such a capacity - the semi-periphery might, alternatively, extend its innovative policies of mixing selection and transformation, culturally specific forms with universally progressive forms of development, to the peripheries. Eventually, an innovative semiperiphery may influence concomitant changes in the core zone.

To meet the need for alternative designs of development, some concepts of sustainable development, especially culturally sustainable development, may be appropriate. Within a variety of concepts of sustainable development (cf. Neederven Pietrsee 2010; Kassel 2012), and culturally sustainable development in particular (cf. Bornshier 2005; Radcliffe 2006; Sacco, Blessi and Nuccio 2009), a concept of culturally oriented sustainable development is presented in the national document Croatia in the $21^{\text {st }}$ Century: The Strategy of Cultural Development (Cvjetičanin and Katunarić 2003), which was discussed in the Croatian parliament, but was not adopted ${ }^{14}$, and, thus, could not be implemented in the national policy. The main idea of this strategy is closest to the assumption that socio-cultural evolution creates hybrids rather than pure types. The following quotation from the document illustrates the meanings of a culturally oriented sustainable development: "/C/ultural development in Croatia should focus on principles of sustainable development. To that end it is necessary to mobilize cultural heritage resources and new forms of artistic expression; initiate domestic cultural industries; raise the level of art education; step out from a strictly delineated cultural space

14 The document was accepted by a majority vote, instead of a parliamentary consensus, the precondition for proceeding with the implementation. In other countries of Europe, as well in Canada, the situation with different strategies, more or less relevant to culturally sustainable development, is rather similar (cf. http://www. culturalpolicies.net/web/index.php). 
into everyday cultural life; open up numerous channels of inter-sector cooperation; enhance relations towards other cultures; etc. The long-term goal of such activities is sustainable cultural development, which implies:

a. increasing the interest of the population in quality products of elite, traditional, and alternative cultures,

b. developing needs, the meeting of which will alleviate the strain on natural resources and existing capacities of infrastructure and inhabited areas,

c. strengthening social cohesion and communication outside the traditional frameworks of social identity and defusing social-Darwinist aspirations." (Cvjetičanin and Katunarić 2003: 165).15

In other words, culturally sustainable development stimulates sustainable economic development, e.g. slowing down the work and life rhythms, by using cultural means, ranging from the artistic design of workplaces to traditional customs or new urban practices concerning food, for example, which unfold slowly and do not take profit as their primary, or their only goal. Surely, owing to the fact that the Croatian strategy has not been implemented so far, the whole case may be seen as an argument a contrario, demonstrating that developmental policies select policies close to pure types or to existing practices favourable to the core - e.g. the privatization-marketization-commercialization chain - rather than to mixed types. My counter-argument is that the former are detrimental to peripheries and semi-peripheries and, in the longer run, to the core. Of course, this argument is still hypothetical. Nevertheless, a scientific argument should not be based on a fait accompli either, which is a variant of the fundamental(istic) belief that the real-existing economy and society is the best one at the same time. This is also a tenet of sophisticated militaristic regimes, that originates from Plato's The Republic, in which the sophist Thrasymachus defines justice - which is a political version of the meaning of truth - as "the right of the stronger" (Plato 1992).

The concept of a culturally oriented sustainable development concerns a broad selection of diverse elements of cultural institutions and practices

15 In the Strategy document, the points $a, b$ and c constitute the elements of the definition of a culturally sustainable or culturally oriented development (see also: Cvjetičanin and Katunarić 2012). 
that fit a post-neoliberal and post-statist era, cultural and other policies (education, health, housing, employment...). A sustainable economy/ society combines elements of market and state regulation in different proportions, adapted to conditions of individual countries, regions, and people(s). A sustainable society combines elements of association and solidarity with individual independence and competition. Sustainable (democratic) politics consist of a triangle of representative democracy, meritocracy (parliamentary houses with experts from different areas), and basic or immediate democracy (as a corrective of the local and national political institutions' decision-making). Such politics put forward soft rather than hard power (resources), by using persuasion rather than coercion. Finally, a sustainable cultural and scientific policy combines quality products of different cultural and scientific styles, and propagates them through education and the media, as well as through popular places of public gathering.

\section{Why are hybrids more sustainable than pure types?}

By borrowing from, rather than polarizing, the free market and the stateplanning systems, hybridization contributes to organizing development in the context of different cultures in the globalizing world (cf. Galtung's renunciation of the opposition between Smithism and Marxism in: Galtung 1989). Such an understanding of development policies makes possible the creation of a sustainable development as a set of different, shifting, points or intervals on the scale of developmental policies, between laissezfaire and state dictatorship (Cvjetičanin and Katunarić 2013: 187-190). A sustainable development takes into account both cultural diversities and different levels of development. Also, it is a dynamic process, not a fixed middle course between the extremes. Simply stated, some individuals or organizations are more inclined to competition and uncertainty, while others are more inclined towards solidarity and certainty. These dispositions are unevenly distributed among different cultures. Some cultures are certainty- and others uncertainty-oriented (Hofstede 2002). Nevertheless, for the sake of keeping a dynamic balance of development in different cultures, both tendencies must find their place on the scale of 
development policies. Hybrid policies also correspond to the need for a personal balance between basic, yet opposed, human inclinations, which Rousseau described as amour-propre and amour de soi (cf. Kolodny 2010), and Riesman as other-oriented and inner-oriented behaviours (Riesman 1950).

A (post)modern or high-modern ${ }^{16}$ society must certainly be organized in such a way that people occupy nearly equal positions in a society, and, at the same time, are free to choose between more competitive and more cooperative relations with others. Sustainability of the conditions of equality and freedom are by no means pre-modern values. For instance, feudalism and slavery were technically "sustainable" for centuries, which is a fact favourable to the selectionist paradigm, as the ruling groups were rarely opposed by the subordinated ones (slaves, peasants). Today, such a social order cannot be sustainable in the long run (unless the West changes its political paradigm profoundly - see above regarding threats of "resilience" and protracted wars). Hence, the selectionist paradigm of evolution must be complemented with elements of the transformational paradigm pertinent to modernity, whether in terms of liberalism or socialism. Either way, modern society is, ideally speaking, founded on ethical universalism. It is a postulate according to which people can adapt their behaviour to, or claim the implementation of universal rules (e.g. the ban of homicide), and may want to or be able to transcend the real existing social order, based on deepening social inequalities and/or on violations of human rights, through reforms or revolutions. Such purposive rationality is appropriate for modern societies due to their, in Eisenstadt's words, capabilities of self-correction. Assuming his notion of self-correction reflects the core of the Kantian notion of the transformation of traditional or particularistic morality into universal/modern morality which is instituted in most modern societies through anti-discriminatory legislation. Yet, differences between the de jure and the de facto state of universal norms in various countries or regions leaves enough space for

16 Here, nearly equal meaning is given to both terms because high modernity includes a higher tolerance toward differences. The only difference between the two may be that in high modernity universalism has primacy over particular values. In any case, post-modernity is not only a temporal category in terms of what follows the end of modernity, which really happened, although temporarily, with the rise of Fascism, for example, representing a mixture between a cultural tradition, e.g. anti-Semitism in a good part of medieval and early modern Europe, and new technologies in weaponry and in the media (e.g. radio). Yet, a more important meaning of post-modernity is that it adopts some essential values of modernity - freedom and equality, in the first place - and then insists on their "translation" and recreation in different cultural and economic contexts which, admittedly, may make the meaning of those values relativistic in a certain measure (for instance, as regards debates about individual and collective rights in multiculturalism - cf. Kymlicka 1996). 
self-correction of current democratic societies.

At any rate, units of a globally sustainable society will necessarily vary with regard to the variable importance allotted to institutional spaces for market and solidarity - the principles that are pertinent to democracy as such provided that these principles do not exclude each other. Otherwise, if a society is ruled exclusively by the free market, or by the prerogative state, sooner or later the society will collapse due to resistance of the majorities hit by exclusionary policies.

Surely, the idea of achieving sustainability through mixed modalities of the allocation of material goods and decision-making powers is not entirely new. Max Weber, and long before him Machiavelli, argued that some policy areas and some occupational sectors are inappropriate for democracy, whereas other areas are not appropriate for oligarchic or monarchic rule (cf. Maley 2011). For example, democracy is impractical in science and arts, as these sectors are meritocratic by definition. On the other hand, issues of social and economic justice, including the distribution of income, especially state funding, are inclined towards democratic decision-making. At the same time, in modern education, mixtures of meritocratic competences (of teachers) and participation (of students) are more adequate than meritocracy or educational populism, etc. It can generally be argued that the higher a society is developed with an increase of the better educated population - mixed modalities, that combine elitism and broad participation, are more appropriate. Furthermore, in countries which make attempts at advancing the practice of sustainable development, such as most Scandinavian countries, social inequalities are smaller than in countries such as the United States or North Korea, for example, which deal with pure types of liberal or statist policies, respectively.

Last, but not least, hybrid patterns of development would be easier to maintain by a world government (e. g. by the United Nations, advanced to such a role), than by international contingencies of the laissez-faire economies, or by competition between nation-states or blocs of nationstates. Nevertheless, some nation-states, just like a world government, might be faced with regional or local intransigence derived from some cultural contrast (e.g. between individualism and collectivism), political 
extremism or deeper economic gap. Still, it might be easier to govern such a huge and diverse landscape, as the governance would take place in a world-wide space, in which most units are no longer politically divided with regard to the basic principles of freedom and equality, where extremes and exclusions are rather rare. In the current international arena, consisting of nation-states with unequal powers, where the global market economy, run by big corporations, assisted by the governments of developed countries, any attempts of establishing global regulation and governance are consistently avoided. Conversely, the existing policies of development, marked by the expansion of the neoliberal agenda, favour the rise of extremes. At the same time, a more balanced global policy may have a more favourable impact on less developed countries, and may also produce more adequate solutions in politics and intergroup relations in general. Such a policy may include different forms of socioeconomic development, more or less competitive or cooperative, and democratic decision-making (more representative or more basic democracy - with more or less meritocracy), and a vibrant cultural life (traditional, /post/ modern or combined), rather than treating non-economic dimensions of society as residual or indiscriminate effects of the laissez-fair economy. With the growth of such policies the coordinative role of the state will gain importance as well. ${ }^{17}$

\section{In lieu of a conclusion}

Finally, I would like to again paraphrase Valéry's observation from the beginning of the paper, this time using the metaphor of a "dancer" as proxy for the idea of a culturally oriented sustainable development. Units that may jointly produce a global society which is ecologically sounder and more sensitive to the needs of other units, should neither "dance" without rules nor "calculate" on the basis of their own interests only. The latter brings back the Hobessian state of nature, which was reiterated in The Communist Manifesto as a false alternative leading to "the common

17 "/G/lobalization and state growth have gone hand in hand precisely because economic interdependence or the exposure of social relations to international pressures increases, not decreases, the social utility of the state" (Weiss 2006: 170). 
(2) ruin of the contending classes" (Marx and Engels 1848: 2). Rather, a set of prudent policies of a culturally oriented sustainable development should produce a common habitat for contending parties, compelling them to acquire habits of correcting their initial or crude interests into interests acceptable to other parties. This would be the result of a dialogue for the sake of (Kantian) conviviality. Such an approach to development looks like a skilful dancer, who switches to different rhythms when needed. One rhythm is prescribed by basic rules and is rather monotonous, while the other is rhapsodic and basically improvised, yet both are necessary. This evokes the figure of a dancer depicted in T. S. Eliot's Four Quartets:

"From wrong to wrong the exasperated spirit Proceeds, unless restored by that refining fire Where you must move in measure, like a dancer" (Eliot 1943)

By analogy, a culturally sustainable development represents the skill of self-reliant movement, acquired through a long process of trials and errors. 


\section{Bibliography}

Amin, S., 1990. Mal-Development - Anatomy of a Global Failure. London and New Jersey: United Nations University Press; Tokyo: Zed Books Ltd.

Beck, U., 2005. Power in the Global Age: A New Global Political Economy. Malden, MA: Polity.

Bidet, J., 1999. Théorie générale. Paris: PUF.

Bloch, M., 1989. Feudal Society. Vol 1: The Growth and Ties of Dependence. Routledge.

Bornschier, V., ed., 2005. Culture and Politics in Economic Development. Routledge.

Bürkner, H. J. and Matthiesen U., 2007. Territorial Cohesion, Brain Drain and Digital Divide. In: Scholich, D., ed., Territorial Cohesion. Berlin, Heidelberg: Springer Verlag.

Castells, M., 1998. End of Milenium. Blackwell.

Cvjetičanin, B. and Katunarić, V., eds., 2003. Hrvatska u 21. stoljeću: strategija kulturnog razvitka [The Strategy of Cultural Development - Croatia in the $21^{\text {st }}$ century]. Zagreb: Ministarstvo kulture Republike Hrvatske.

Cvjetičanin, B. and Katunarić, V., 2012. Croatian Culture in the European

Union. Available at: www.culturelink.org/news/members/2012/ members2012-006.html (accessed 4 January 2013).

Darwin, C., 2002. The Descent of Man. In: Wyhe, J. van, ed. The Complete Work of Charles Darwin Online. Available at: http://darwin-online. org.uk/ (accessed 29 December 2012).

Duxbury, N. and Gillette E., 2007. Culture as a Key Dimension of Sustainability: Exploring Concepts, Themes, and Models. Working Papers No 1. Creative City Network of Canada. Available at: http:// cultureandcommunities.ca/downloads/WP1-Culture-Sustainability. pdf (accessed 8 February 2013). 
Eliot, T. S., 1943. Four Quartets. Available at: www.coldbacon.com/poems/ fa.html (accessed 5 February 2013).

Eisenstadt, S. N., 2002. Multiple Modernities. New Jersey: Transaction Publishers.

Fine, B., 2002. Economics Imperialism and the New Development Economics as Kuhnian Paradigm Shift. World Development, 30(12): 2057-70.

Fracchia, J. and Lewontin R. C., 1999. Does Culture Evolve? History and Theory, 38(4): 52-78.

Fracchia, J. and Lewontin, R. C., 2005. The Price of Metaphor. History and Theory, 44(February): 14-29.

Galtung, J., 1989. Theory formation in social science: a plea for pluralism. In: Øyen E., ed., Comparative Methodology. London: Sage.

Global Poverty Statistics, 2006. Available at: www.banzaid.org.nz/index. php?...63\%3Apovert... (accessed 28 December 2012).

Hayek, F. A., 1979. Counter-Revolution of Science. Indianapolis: Liberty Press.

Hegel, G. W. F., 1979. Grundlinien der Philosophie des Rechts. Werke. Band 7, Frankfurt a. M.: Suhrkamp.

Held, D. and McGrew A., eds., 2007. Globalization Theory: Approaches and Controversies. Oxford: Polity.

Hicks, D., 2013. One size doesn't fit all: On the co-evolution of national evaluation systems and social science publishing, Confero, 1(1): 67-90.

Hofstede, G. and Hofstede G. J., 2005. Cultures and Organizations: Software of the Mind, Intercultural Cooperation and Its Importance for Survival. McGraw-Hill Companies (UK)

http://www.culturalpolicies.net/web/index.php (accessed 3 May 2014).

http://www.uncsd2012.org/history.html (accessed 10 January 2013).

Human Development Report (HDR), 2013. Available at: www.hdr.undp. org/ (accessed 11 January 2014). 
Kaplan, D. and Manners R. A., 1972. Culture Theory. New Jersey: PrenticeHall.

Kassel, K., 2012. The Circle of Inclusion: Sustainability, CSR and the Values that Drive Them. Journal of Human Values, 18(2): 133-146.

Katunarić, V., 2009. Building sociological knowledge within and across disciplinary boundaries: megalomania vs. modesty? Innovation The European Journal of Social Science Research, 22(2): 155-171.

Katunarić, V., 2011. Causes of parochial status in international knowledge production. In: Belyaev, D. and Roca, Z., eds., Contemporary Croatia: Developmental Challenges in a Socio-Cultural Perspective. Lisboa: Edições Universitárias Lusófonas.

Kymlicka, W., 1996. Multicultural Citizenship: A Liberal Theory of Minority Rights. Oxford University Press.

Knorr-Cetina, K., 1997. Sociality with Objects. Social Relations in Post-social Knowledge Societies. Theory, Culture \& Society, 14(4): 1-30.

Klein, N., 2007. The Shock Doctrine: The Rise of Disaster Capitalism. New York: Metropolitan Books / Henry Holt.

Maley, T., 201 1. Demo Political in Max Weber's Thought. Toronto: University of Toronto Press.

Marx, K. and Engels F., 1848. Manifesto of the Communist Party. Available at: http://www.marxists.org/archive/marx/works/1848/communistmanifesto/ (accessed 4 January 2013).

Marx, K. and Engels, F., 1970. Selected Works. Volume Three. Moscow: Progress Publishers.

Nederveen Pieterse, J., 2010. Development Theory. Sage.

Plato, 1992. The Republic by Plato. Available at: http://www.idph.net (accessed 5 January 2013).

Polanyi, K., 2001. The Great Transformation. The Political and Economic Origins of our Time. Boston, Ma.: Beacon Press.

Radcliffe, S. A., ed., 2006. Culture and Development in a Globalising World: Geographies, Actors, and Paradigms. Routledge. 
Riesman, D., 1950. The Lonely Crowd: A Study of the Changing American Character. New Haven: Yale University Press.

Runciman, W. G., 1989. A Treatise to Sociological Theory. Vol. Il. Cambridge, UK: Cambridge University Press.

Runciman, W. G., 2005. Culture Does Evolve. History and Theory, 44(1): $1-13$.

Runciman, W. G., 2006. The Theory of Cultural and Social Selection. Cambridge, UK: Cambridge University Press.

Sacco, P. L., Blessi, G. T. and Nuccio, M., 2009. Cultural Policies and Local Planning Strategies: What Is the Role of Culture in Local Sustainable Development? The Journal of Arts Management Law and Society, $39(1): 45-6$.

Sahlins, M. D., 1970. Evolution. Specific and General. In: Sahlins M. D. and Service, E. R., eds., Evolution and Culture. Ann Arbor: The University of Michigan Press.

Shils, E., 1975. Center and Periphery. Essays in Macrosociology. Chicago: University of Chicago Press.

Sörensen. J. S. and Söderbaum, F., 2012. The End of the DevelopmentSecurity Nexus? In: Sörensen. J. S. and Söderbaum, F., eds., The End of the Development-Security Nexus? The Rise of Global Disaster Management. Development Dialogue, 58: 7-20.

Spencer, H., 1896. The Study of Sociology. New York: D. Appleton and Company.

Stiglitz, J., 2010. Freefall: America, Free Markets, and the Sinking of the World Economy. London: W.W. Norton \& Company.

Suvin, D., 2010. Defined by a Hollow: Essays on Utopia, Science Fiction and Political Epistemology. Berlin: Peter Lang Verlagsgruppe.

Tönnies, F., 2005. Gemeinschaft und Gesellschaft. Grundbegriffe der reinen Soziologie. Darmstadt: Wissenschaftliche Buchgesellschaft.

Valéry, P., 1934. Autres Rhumbs. Paris: NRF Librairie Gallimard.

Varoufakis, Y., 2008. Capitalism According to Evolutionary Game Theory: The Impossibility of a Sufficiently Evolutionary Model of Historical 
Change. Science \& Society, 72(1): 63-94.

Wallerstein, I., 1990. Culture as Ideological Battleground of the Modern World-System. In: Featherstone, M., ed., Global Culture. Sage.

Wallerstein, I., 2001. The End of the World As We Know It: Social Science for the Twenty-First Century. Minneapolis, MN: University of Minnesota Press.

Wallerstein, I., 1992. The West, Capitalism, and the Modern World-System, Review, 15(4): 561-619.

Weiss, L., 2005. Infrastructural power, economic transformation, and globalization. In: Hall, J. A., Schroeder, R., eds., An Anatomy of Power. The Social Theory of Michael Mann. Cambridge University Press.

Wuketits, F. M. and Antweiler, C., eds., 2004. The Evolution of Human Societies and Cultures. Wemheim: Wiley-VCH Verlag GmbH \& Co KGaA.

Ziegler, J., 2005. L' empire de la honte. Paris: Fayard.

Vjeran Katunarić (vjeran.katunaric@zg.t-com.hr) is professor in the Department of Sociology at the University of Zadar, Croatia. His books and research articles deal with subjects as diverse as the socioeconomic position of migrant workers, women and society, the decomposition of society, recent theories of nation and nationalism, and culture and development. He was a guest professor in the USA and Sweden, and a cultural policy expert of the Council of Europe. In 1998 he was director of the project "Croatian Cultural Policy - National Report", and in 2002 a coordinator of the project "Cultural Development in Croatia in the $21^{\text {st }}$ Century". 